This is a self-archived version of an original article. This version may differ from the original in pagination and typographic details.

Author(s): Lahti, Malgorzata; Valo, Maarit

Title: Intercultural Workplace Communication

Year: 2017

Version: Accepted version (Final draft)

Copyright: (c) Oxford University Press, 2017.

Rights: In Copyright

Rights url: http://rightsstatements.org/page//nC/1.0/?language=en

Please cite the original version:

Lahti, M., \& Valo, M. (2017). Intercultural Workplace Communication. In Oxford Research

Encyclopedia of Communication. Oxford University Press.

https://doi.org/10.1093/acrefore/9780190228613.013.404 


\title{
Intercultural Workplace Communication
}

\author{
Malgorzata Lahti and Maarit Valo \\ Oxford Research Encyclopedia of Communication \\ Subject: Communication and Culture, Interpersonal Communication \\ Online Publication Date: Jul 2017 DOI: 10.1093/acrefore/9780190228613.013.404
}

\begin{abstract}
Summary
The workplace is a highly meaningful context for intercultural communication where persons who come from different countries, identify with different ethnic groups or speak different languages get to collaborate and develop relationships with one another. Needless to say, interpersonal communication in the workplace has always been a primary area of interest for intercultural communication research.

Early scholarship focused on the preparation of U.S. military personnel, diplomats, business people, and missionaries for overseas assignments. However, the increasing pluralization of the social landscape has bolstered research endeavors. These days, the scope of intercultural workplace communication inquiry comprises everyday face-to-face and technologymediated interactions in encounters, relationships, groups, and teams in a variety of working arrangements, and across a range of public and private sector organizations worldwide. The scholarship also draws on the organizational approaches of antidiscrimination and diversity management that emerged in the United States and have subsequently been exported to and reinterpreted in workplaces around the world.

Researchers have looked into such workplace communication processes and phenomena as social categorization, stereotyping, prejudice and discrimination, conflict and its management,


organizational satisfaction and identification, socialization, supportive communication, interpersonal relationship development and informal interaction, negotiation of shared workplace culture, knowledge sharing, decision-making, learning and innovation, or leadership and management. In recent years, there has been a growing interest in the ways languages are used in interactions at work.

\section{Keywords}

cultural diversity, cultural identity, intercultural communication, intergroup communication, interpersonal communication, organizational diversity, working life groups and teams, workplace, workplace relationships

\section{Intercultural Communication: A Challenge and a Resource in the Workplace}

In today's increasingly pluralistic societies, the workplace has emerged as an important context where persons with different cultural backgrounds come together and develop relationships with one another. Intercultural workplace communication denotes a symbolic process where two or a few individuals with different cultural memberships create and negotiate meanings in professional contexts (see Braithwaite, Schrodt, \& Carr, 2015). Intercultural communication research has traditionally focused on interactions between people who come from different countries, speak different first languages, or identify with different ethnic groups.

The ways in which people's different cultural memberships could surface in communication at work may be consequential for individuals, groups, organizations, and societies; they may also be distinctive from communicative considerations in other realms of human activity (Hua, 2014). The workplace is not merely a container where intercultural communication occurs (see Sias \& 
Cahill, 1998). It is a social site that is both shaped by and shaping communicative practices among its members and between its members and outside stakeholders (Gibbs, Nekrassova, Grushina, \& Wahab, 2008). Practically all phenomena that are at the core of organizational functioning, such as decision-making, leading and following, conflict management and its resolution, or socialization, are inherently communicative (see Sias, 2009). By the same token, the workplace context informs people's interactions in highly meaningful and consequential ways. It limits and enables specific experiences of self, roles, activities, pursuits, relationships and encounters, and imbues them with social and economic implications (Hua, 2014).

Communication between people at work often takes place in the context of workplace relationships or interpersonal bonds between persons who engage in recurrent interactions over time (Sias, 2009). Examples of these include peer-coworker, subordinate-supervisor or business partner relationships. Workplace relationships stand apart from one-off encounters with strangers that are characteristic of, for instance, customer service work. Working life communication also encompasses interactions in small groups and, increasingly, teams. A team is a small group of individuals with diverse knowledge and skills who work interdependently on shared tasks towards common goals (e.g., Scott, 2013). Teams have gained prominence in the growing sector of knowledge-intensive work that depends on shared and creative development of solutions to emergent challenges (see Blyton \& Jenkins, 2007). Rapid developments in communication technologies have enabled organizations to utilize technology-mediated work, especially in the context of distributed or virtual teams. Rather than sharing a physical location and working mostly face-to-face, members of virtual teams are geographically, and often internationally, dispersed and largely rely on technologies for collaboration (e.g., Klitmøller \& Lauring, 2013). 
The topic of intercultural communication at work has encouraged intense scholarly interest. The inquiry comprises everyday face-to-face and technology-mediated interactions between peer coworkers, subordinates, supervisors and business partners, communication in small groups and teams, and encounters with customers in a variety of working arrangements, and across a range of public and private sector organizations around the world. Investigations into the topic have been conducted across disciplines and research perspectives, such as management, human resources, communication, applied linguistics, sociology, organizational psychology or critical, postcolonial, and feminist studies. This goes to show that intercultural workplace communication has evolved into a highly heterogeneous and multidisciplinary field of inquiry.

We can trace the widespread interest in the topic back to organizational, social, and political developments in the United States. This is where intercultural communication and cultural diversity first emerged as objects of systematic inquiry and organizational practice (Ashkanasy, Härtel, \& Daus, 2002; Holvino \& Kamp, 2009; Leeds-Hurwitz, 1990). Early developments in the field of intercultural communication (e.g., Hall, 1989) established an understanding of intercultural communication as an arena where national cultural differences between individuals become evident. At the same time, the approaches of antidiscrimination and, later on, diversity management arose in U.S. organizational contexts (e.g., Lorbiecki \& Jack, 2000). These conceive of cultural differences among organizational members as, respectively, the basis for systemic discrimination of minority employees or as an organizational resource.

The early preoccupations in the field of intercultural communication and the developments in organizational diversity approaches have concurred to produce two discrete ways of discussing intercultural workplace communication (Lahti, 2015a). According to the general understanding of the topic, national and ethnic cultures shape people in distinctive ways. These 
essential differences may act as (1) an organizational challenge; or as (2) an organizational resource. In fact, intercultural issues in the world of work have been described in the literature as a "double-edged sword" (e.g., Stahl, Maznevski, Voigt, \& Jonsen, 2010). There have been many studies about misunderstandings in professional communication among persons who have different national or ethnic backgrounds and speak different first languages (e.g., Mak \& Chui, 2013). Researchers have also shown that organizational members are less willing to share information or develop interpersonal relationships with colleagues they perceive to be culturally dissimilar to them (e.g., Ferguson \& Porter, 2013). Another line of inquiry has documented how representatives of cultural minority groups experience mistreatment and pressures to conform to the mainstream organizational culture (e.g., Kamenou \& Fearfull, 2006). Meanwhile, some scholars have argued that differences in employees' cultural perspectives, knowledge, and skills enhance decision-making and problem solving, and stimulate individual and organizational learning (e.g., Ely \& Thomas, 2001; García \& Cañado, 2011).

In the context of technology-mediated working life communication, virtuality has generally been treated as an additional variable that intensifies or mitigates the impact of cultural diversity (for reviews, see Connaughton \& Shuffler, 2007; Gibbs et al., 2008; Gibson, Huang, Kirkman, \& Shapiro, 2014). Research has typically looked into the combined negative effects of cultural diversity among people working together and the constraints of technology-mediated interaction, such as undermined knowledge sharing and establishment of mutual knowledge base, misinterpretations of the others' actions and intentions, conflict related to work coordination or problems addressing existing conflicts (e.g., Zakaria, Amelinckx, \& Wilemon, 2004). A number of studies have explored the conditions for harnessing the possibilities for learning and creativity, and turning globally dispersed collaboration productive (e.g., Scott, 2013). 
As we can see, the dualistic understanding of intercultural workplace communication as either an organizational asset or challenge has produced mixed and inconclusive findings. Not surprisingly, the traditional research approach that focuses on the salience and impact of cultural differences on workplace communication has been increasingly called into question. A more recent line of inquiry has approached culture and cultural difference as social constructs produced rather than revealed in communication (e.g., Barinaga, 2007; Lauring, 2011). These studies have argued that meanings of cultural identities are context-specific, multidimensional, dynamic, and unpredictable. The scholarship has further suggested that people's different backgrounds are not always salient in communication at work. The workplace context offers myriad resources for people to construct and cherish consensus and similarity rather than difference (e.g., Ryoo, 2005; Schnurr \& Zayts, 2013). There has also been a research thrust into linguistic practices in workplace interactions (e.g., Lønsmann, 2014; Lüdi, 2013). In these explorations, language no longer figures as a neutral conduit for culture. The focus is on how people's competence in the dominant language of the workplace informs their communication and participation in organizational life.

To summarize, the field of intercultural workplace communication inquiry is heterogeneous and vibrant in the phenomena and contexts examined. And yet, it also is constrained by specific theoretical considerations that pivot on the fundamental question of how culture should be defined. This chapter maps what we know and what we do not know about the topic of intercultural communication at work. It examines research origins, developments, perspectives, main findings, trends, and challenges, and it ends with a list of suggestions for directions that future inquiry could take. 


\section{Workplace Communication as Central to Intercultural Communication}

\section{Research}

Interpersonal communication in professional contexts has always been a primary drive and area of interest for intercultural communication research. Early investigations and training activities emerged in the post-WWII United States. They were internationally-oriented and mostly concerned with the preparation of military personnel, diplomats, business people, and missionaries for overseas assignments (Leeds-Hurwitz, 1990). Foundational to these developments was Edward Hall's work at the Foreign Service Institute (FSI) (Leeds-Hurwitz, 1990).

At the behest of the FSI, Hall developed a practical approach to culture that could be easily implemented in trainings to sensitize diplomats to cultural differences that may impede professional communication (Breidenbach \& Nyíri, 2009). This approach entailed seeing communication as predictable, decontextualized, and objectively analyzable, with an emphasis on the method of comparing different cultural systems (Moon, 1996). Hall (1989, 1990) proposed that social groups can be divided into those that are "low context" and "monochronic" versus those that are "high context" and "polychronic." He pointed to nation-states as the location of culturally unique ways of life and emphasized that opposite cultural systems are irreconcilable (Breidenbach \& Nyíri, 2009). Intercultural communication thus came to be seen as an arena where (mostly incompatible) national cultural differences are manifested.

The groundwork laid by Hall has been built upon in the research of Geert Hofstede. Hofstede's work (e.g., Hofstede, 1980, 1991, 2001; Hofstede, Hofstede, \& Minkov, 2010) is preoccupied with nation-based differences in work-related values. Culture is equated with a nation-state and treated as a variable responsible for differences in people's motivations, 
attitudes, and behavior. Drawing on questionnaire survey data gathered from IBM employees across 72 countries, Hofstede (1980) identified four universal value orientations against which different nations could be compared: "power distance," "collectivism/individualism," "masculinity/femininity," and "uncertainty avoidance." More dimensions have been added after further data collections (e.g., Hofstede, 2011; Hofstede et al., 2010). The approach of Hall and Hofstede echoes in other cultural dimensions models focusing on intercultural communication in the world of work (e.g., Trompenaars \& Hampden-Turner, 1997).

This line of research sees culture as a fairly stable and homogeneous system of values, schemes for interpretation, and behavioral traits. These are contained in a national or ethnic group, expressed through a national language, and they shape people's communication in mostly unacknowledged ways. Professionals can make their communication more competent by developing awareness of and adapting to the culturally distinctive ways of their foreign colleagues, partners, or clients. The idea that national or ethnic memberships endow people with specific psychological and discursive traits has been consequential for intercultural communication research in general (Mendoza, Halualani, \& Drzewiecka, 2002).

\section{Organizational Approaches to Cultural Diversity}

Intercultural communication in professional contexts ceased to be understood as an exclusively overseas matter when it was introduced into discussions about cultural diversity in U.S. working life in the 1960s. The civil rights and women's movements engaged in political struggle to combat the systemic oppression experienced by women and African-Americans in U.S. social and organizational life, laying foundations for the approach of antidiscrimination (Prasad, 2001). 
Antidiscrimination treats ethnicity-, religion-, and gender-based difference as a political issue. It recognizes that group membership may serve as a basis for discrimination and posits that such discrimination should be addressed through hard-type initiatives (Wrench, 2005). These initiatives, known under such names as equal employment opportunity or affirmative action, are meant to increase the participation of members of historically disempowered and underrepresented groups in organizational life (for instance through observing stringent antidiscrimination policies or introducing quotas for hiring and promotion).

In the 1980s, antidiscrimination found a possible successor in the alternative approach of diversity management (Holvino \& Kamp, 2009). A harbinger of the imminent shift in organizational sensitivities, the Workplace 2000 Report published by Johnston and Packer in 1987 cautioned organizations that by the year 2000 the U.S. work force would be mostly composed of women and members of ethnic minority groups (Lorbiecki \& Jack, 2000). This compelling projection inspired both corporate management and academia to scrutinize possible impacts of cultural diversity on organizational functioning and outcomes (Lorbiecki \& Jack, 2000).

Diversity management offers an all-inclusive view by proclaiming an interest in cultural experiences and characteristics of all employees, not just minority group members (Lorbiecki \& Jack, 2000; Wrench, 2005). It further draws on economic argumentation, claiming that by skillfully managing cultural differences among their employees, organizations can achieve more innovative and efficient decision-making, and better meet the demands of increasingly globalizing markets (Lorbiecki \& Jack, 2000). Simply put, the diversity of perspectives, schemes for interpretation, knowledge, skills, and preferences among employees creates an enriched knowledge pool for the management to tap. Rather than implementing structural changes, 
diversity management focuses on honing individuals' interpersonal communication skills (Holvino \& Kamp, 2009). Not surprisingly, the rise of diversity management led to a rapid expansion of intercultural communication training industry (see Breidenbach \& Nyíri, 2009).

In the 1990 s, diversity management became a widely exported managerial practice and came to be adopted by organizations around the world (Omanovic, 2009). However, its apparent global acclaim has met with wide-ranging critique for concealing the ongoing systemic oppression on the basis of group membership, ignoring the structural dimensions of workplace discrimination, flattening out individuals' identities to a set of simplistic dimensions of difference, and imposing a universal set of managerial practices onto workplaces characterized by their own unique conditions and intercultural preoccupations (e.g., Konrad, 2003; Litvin, 2006; Zanoni \& Janssens, 2007). However, diversity management has not simply supplanted antidiscrimination. There is ample research evidence that the two approaches tend to be blended and modified to better meet the needs of different local organizational realities (e.g., Kamp \& HagedornRasmussen, 2004; Klarsfeld, 2009; Ostendorp \& Steyaert, 2009).

\section{Predominant Theoretical Frameworks in Intercultural Workplace}

\section{Communication Research}

Concerns embraced by antidiscrimination and diversity management resonate with the popular theoretical underpinnings of intercultural workplace communication scholarship (Lahti, 2015a). These theoretical frameworks are modern critical theory, information and decision-making, and social identity and categorization (see Lauring, 2009).

Modern critical theory (see Baxter \& Asbury, 2015) is associated with antidiscrimination. This theorizing aims to unmask totalizing and stable oppressive systems (such as structural 
organizational inequities or the ideology of diversity management) that advance the interests of some groups while sanctioning the discrimination of others.

The frameworks of information and decision-making and social identity and categorization can, on the other hand, be linked to diversity management. The information and decision-making framework (e.g., Distefano \& Maznevski, 2000; Mannix \& Neale, 2005) examines the effect of differences associated with individual members' culturally shaped interpretations, knowledge, and skills on task performance. While cultural differences may lead to misinterpretations, disturbed information flow, or impaired relational development, they can also trigger more creative and effective decision-making and learning on both individual and group level.

According to the traditional socio-psychological framework of social identity and categorization (e.g., Tajfel \& Turner, 1979; Turner, 1987), people will use social cues to categorize themselves and others as members of specific groups, and they will exhibit bias towards out-group members. National, ethnic, and linguistic memberships have been treated as evident common denominators triggering the formation of subgroups. This, in turn, prevents individuals from developing relationships and sharing information with members of the perceived out-group.

\section{Perspectives in Intercultural Workplace Communication Research}

Three perspectives on intercultural workplace communication can be identified in the literature: cultural difference in workplace communication, intercultural negotiation in workplace communication, and inequality in workplace communication. 


\section{Cultural Difference in Workplace Communication}

These studies emphasize that people may have different workplace communication norms and interpretations related to their cultural memberships. National and ethnic memberships are seen as characterized by coherent systems of unique values, beliefs, and practices expressed through language. Scholarship tends to draw on the framework of information and decision-making. Cultural memberships are assumed to exert influence on people's communicative conduct in mostly unacknowledged ways, rendering intercultural communication at work as possibly problematic. The meeting of different communication styles and practices may result in misunderstandings that hinder both relational development and the performance of tasks. However, if managed well, culturally diverse workplace relationships and teams may result in learning and creativity for both individuals and the organization as such. Research aims to document nation- and ethnicity-based values and communication practices and to examine or make predictions about the effect of cultural differences on workplace interaction.

\section{Intercultural Interaction}

Scholars have examined challenging workplace communication situations where participants' diverse national or ethnic cultural traits and practices surface, such as misinterpretations arising from divergent norms for nonverbal communication (Ngai, 2000) or small talk (Mak \& Chui, 2013). Research into technology-mediated interactions of internationally dispersed teams has found that cultural differences combine with limited opportunities for communication, leading to hindered efficiency and impaired relational development (Hinds \& Mortensen, 2005; Zakaria, Amelinckx, \& Wilemon, 2004). However, other researchers (García \& Cañado, 2011; Gibson \& 
Grubb, 2005) have associated culturally diverse teamwork (both co-located and globally dispersed) with positive outcomes such as cohesion, trust, innovation, and personal growth.

\section{Corporate Management Communication}

Human resource and strategic management research has explored the role and strategies of managers in multinational corporate workplaces in mitigating the negative effects and harnessing the possibilities of cultural differences among their staff. As the argument goes, effective management of cultural differences will not only minimize misunderstandings and conflicts, but it may also lead to improved decision-making, synergies, and organizational learning.

Researchers have mostly focused on effective leadership strategies, skills and expectations (Aritz \& Walker, 2014; Camiah \& Hollinshead, 2003; Chevrier, 2003; Mayer \& Louw, 2012), as well as on communication challenges in interactions, usually between Western expatriates and local employees in Eastern European or Asian subsidiaries (Camiah \& Hollinshead, 2003; Peltokorpi, 2007; Vallaster, 2005). With reference to the synergistic effects of cultural diversity, Lauring (2009) has warned that the presence of a range of national categories among the staff does not itself account for enhanced knowledge sharing. Instead, effective management should consider issues of language competence, power relations, and interactional norms prevalent in the organization.

\section{Cultural Uniqueness}

This line of inquiry has described workplace communication norms, practices, and interpretations unique to one or a few specific national/ethnic groups in order to explain or predict workplace communication challenges involving members of those groups. Researchers have examined, for instance, Russian and U.S. managers' understandings of intercultural 
communication competence (Matveev, 2004), impression management behavior of Israelis and Russian immigrants (Zaidman \& Drory, 2001), African-American and European-American women's attitudes to workplace conflict (Turner \& Shuter, 2004), and the importance assigned to the same interaction behaviors by members of virtual teams from the United States, India, and Belgium (Dekker, Rutte, \& Van den Berg, 2008). A number of studies conducted within the Wellington Language in the Workplace project (e.g., Holmes, Vine, \& Marra, 2009; Holmes, Marra, \& Schnurr, 2008; Marra \& Holmes, 2008) have identified differences in communication practices in predominantly Maori or Pakeha workplaces in New Zealand.

\section{Cultural Variability}

These studies test comparatively universal dimensions of organizational behavior to establish how workplace communication values and practices vary across national groups. Research has found a number of national cultural differences in, for instance, Americans' and Koreans' responses to inequity in coworker friendships (Westerman, Park, \& Lee, 2007), organizational dissent and workplace freedom of speech in Finland, France, Germany, Spain and the United Kingdom (Croucher, Parrott, Zeng, \& Gomez, 2014), Thai and American bankers' perceptions of intra- and intergenerational communication (McCann \& Giles, 2006) or American and Russian managers' cross-cultural communication competence (Matveev \& Nelson, 2004). However, cultural similarities have also been reported, as in expected leadership styles and cultural values of Taiwanese and American university employees (Wu, 2008), aspects of Chinese and Western management practices (Wang \& Murphy, 2010), or basic functions of leadership (Shin, Heath, \& Lee, 2011). 


\section{Cultural Awareness Training}

This scholarship has identified a positive effect of cultural awareness training on the development of individuals' communication competence in intercultural interactions at work (Sun, 2013; Ulrey \& Amason, 2001).

\section{Language and Culture}

This work approaches intercultural communication as interaction between speakers of different first languages. It relies mostly on the framework of linguistic relativism according to which different languages encode specific ways of interpreting the social world. Researches have warned that communication situations involving speakers of different first languages, facilitated either through interpreters or a shared language, may be replete with misunderstandings (e.g., Bilbow, 2002; Gavioli \& Baraldi, 2011; Henderson, 2005; Loosemore \& Lee, 2002). A group of studies have identified challenges associated with the use of Business English Lingua Franca (BELF), which, ideally, should be a neutral communication code shared by the global business community (Charles, 2007; Louhiala-Salminen, Charles, \& Kankaanranta, 2005; Pullin, 2010). On a more positive note, in their study into the impact of cultural and linguistic differences on knowledge sharing in Danish-Indian virtual teamwork, Klitmøller and Lauring (2013) found that lean communication media (such as email) alleviated such language-related causes of misunderstanding as the use of local accents or informal expressions.

\section{Intercultural Negotiation in Workplace Communication}

The focus within this perspective is on how individuals understand and negotiate their workplace interactions as intercultural. The underlying assumption is that intercultural communication is a 
situated, dynamic, subjective and intersubjective process. Language is no longer treated as a neutral conduit for culture, and the interactional implications of individuals' different linguistic competencies are considered. Scholarship is informed by the theoretical perspective of social identity and categorization. Investigations seek to shed light onto conditions and situations where cultural identification can be beneficial for organizational functioning.

\section{Cultural Identification}

These studies look into how individuals perceive and negotiate their cultural identities at work. A big portion of the literature has examined the effects of cultural identification onto group outcomes, producing mixed findings. Scholars have shown that perceptions of national or ethnic cultural difference may trigger social identity and categorization processes that encourage intergroup bias, impaired socialization, and hindered collaboration (e.g., Bacharach, Bamberger, \& Vashdi, 2005; Brief et al., 2005; Ogbonna \& Harris, 2006). National stereotyping and the creation of subgroups can be intensified in the context of global virtual teamwork where possibilities for interacting with one's remote colleagues are limited (Au \& Marks, 2012). Luijters, van der Zee, and Otten (2008) have argued that strong national or ethnic identification can actually be prevented by a superordinate team/organizational identity that appreciates differences.

In contrast to the above, some research has argued for positive outcomes of social categorization. Seeing someone as culturally dissimilar may trigger assumptions of informational differences, encouraging more profound discussions that lead to more effective decision-making (Ayoko, Härtel, \& Callan, 2002).

Moreover, some authors (Dickson, Hargie, \& Wilson, 2008; Lahti, 2013; Ryoo, 2005; Schnurr \& Zayts, 2013) have suggested that there may be situations and contexts where 
organizational members do not perceive their cultural identities as relevant. Interaction-centered approaches have enabled researchers to explore the dynamic, relational, socially constructed, and contextualized character of the process of cultural identification in the context of face-to-face shopkeeper-customer interaction (Busch, 2010), cultural knowledge sharing in virtual teamwork (Lahti, 2015b), and call center work in India (Pal \& Buzzanell, 2008).

\section{Understanding Cultural Diversity}

Research has identified a number of factors that shape people's perceptions of cultural diversity at work. Examples include group composition (Oetzel, McDermott, Torres, \& Sanchez, 2012), the demands and characteristics of the specific workplace (Aries, 2004; Irizarry \& Gallant, 2006), as well as the individual's own "minority status" (Al-Jenaibi, 2011; Nazione \& Silk, 2011; Soni, 2000). Interpretations given to cultural diversity are an important research topic as they may have an impact on organizational functioning. In their seminal study, Ely and Thomas (2001) have demonstrated that the general attitude towards diversity held in a work group has a bearing on how people understand the role of their cultural identity at work, how they express and deal with diversity-related tensions, and whether cultural minority employees feel appreciated in the organization. The perspective on diversity may thus be a stronger predictor of organizational efficiency than the objective demographic categories represented in employees' backgrounds. Similarly, research into virtual teaming has proposed that a perception of national team diversity as an asset is positively related with learning and creativity (Cramton \& Hinds, 2005; Gibson \& Gibbs, 2006).

Scholarship approaching culture from social constructionist frameworks as a purely discursive concept has found that members of international teams may draw upon "cultural diversity" to construct a highly positive image of their collaboration (Barinaga, 2007). 
Alternatively, people may use "cultural diversity" as a scapegoat for interpersonal communication problems (Dameron \& Joffre, 2007).

\section{Shared Culture}

This work has looked into how members of international groups negotiate aspects of their cultural backgrounds to create a local working culture. Studies have focused on the effects of group composition and faultlines on hybrid culture development (Earley \& Mosakowski, 2000) and cultural negotiation as an unpredictable and dynamic process (Brannen \& Salk, 2000; Salk \& Brannen, 2000), as well as the development of ritualized forms of interaction that mitigate the challenges of globally dispersed virtual teamwork (Scott, 2013).

\section{Intercultural Communication Training}

A number of researchers have argued that training should move away from building awareness of different cultural traits. Instead, trainees should be provided with practical tools for everyday interactions at work that entail the exercise of power, relational development, or negotiation of workplace roles and identities (Charles \& Marschan-Piekkari, 2002; Cooke, Brown, \& Zhu, 2007; Hite \& McDonald, 2006). Following an analysis of training needs in global virtual teams, Lockwood (2015) points out that attending to the symptoms of unproductive collaboration, such as perceived cultural difference, will not alleviate the essential problem of professional disempowerment and distrust in the face of corporate offshoring.

\section{Creative Language Practices}

This work has problematized the mainstay concept of language as a self-contained discrete entity. Researchers have explored emergent creative practices in workplace interactions where, 
rather than speaking one or the other language, interlocutors creatively mobilize their different linguistic repertoires to address the exigencies of the unfolding interaction (Franziskus \& Gilles, 2012; Jansson, 2014; Lüdi, 2013; Otsuji \& Pennycook, 2010). Language choices that support relational development and solidarity among speakers of different first languages have been a recurrent theme in the literature (de Bres, Holmes, Marra, \& Vine, 2010; Nelson, 2014; Okamura, 2009). As Collier's (2011) study has shown, workplace interactions can serve as a vital context for practicing one's skills in the second language.

\section{Language Policies in Multilingual Organizations}

Research has also looked into the communicative challenges associated with the adoption of a common corporate language and a strict language policy, mostly in the context of multinational organizations in Europe (Angouri, 2013; Kingsley, 2013; Mahili, 2014; Tange \& Lauring, 2009; Welch, Welch, \& Marschan-Piekkari, 2001).

\section{Inequality in Workplace Communication}

Scholarship in this perspective highlights the tensions, constraints, injustices, and discrimination that people with nonmainstream cultural backgrounds may face at work. Mostly relying on modern critical theorizing, this research contends that the study of intercultural communication in the workplace cannot ignore larger social structures and ideologies that privilege the interests of some cultural groups over others. The goal of the studies is to uncover marginalized voices, understand how power functions in workplace interactions, and push for social change. 


\section{Challenges Experienced by Minority Employees}

Researchers have looked into the contradictions and discriminatory practices that ethnic minority and immigrant employees experience in U.S. organizational contexts (Deitch et al., 2003; Meares, Oetzel, Torres, Derkacs, \& Ginossar, 2004; Wu \& Buzzanell, 2013). Feminist scholars discuss the concurrent threats to gender and ethnic identities faced by ethnic minority women in the United Kingdom (Fearfull \& Kamenou, 2006; Kamenou \& Fearfull, 2006) and AfricanAmerican and Hispanic women in the United States (Parker, 2001, 2002; Pompper, 2007; Richardson \& Taylor, 2009).

Some investigations have problematized the predominant monolithic view of oppression as top-down. They have approached oppression as complex and dynamic, emerging at the intersections of interpersonal acts of mistreatment and multiple societal and economic structures and ideologies. Examples include research into working life experiences of immigrant workingclass women in U.S. Chinatowns (Shi, 2008) or Filipina and Indonesian domestic helpers in Hong Kong (Ladegaard, 2013).

\section{Contested Workplace Culture}

This line of work has called attention to the contested character of workplace culture that diverse individuals develop through their direct involvement in shared activity. Investigations have focused on an Australian-Samoan development project (Byrnes, 2008), a Saudi branch of a Danish multinational (Lauring, 2011) and a U.S.-Kenyan partnership to promote HIV/AIDS education (Murphy, 2013). 


\section{Language and Inequality}

According to these studies, language ideologies and differing competencies in the dominant workplace language are an inherent part of the mechanism that disempowers and excludes different groups of employees (e.g., Holmes \& Riddiford, 2010; Lauring, 2008; Lønsmann, 2014; Sunaoshi, 2005; Tanaka, 2006). As Piller and Lising (2014) discuss in their study of lowskilled migrant work in the Australian meat industry, linguistic inequality in the workplace may even be maintained by the state to protect industrial interests. Meanwhile, Angouri and Miglbauer (2014) and Park (2013) have observed that the discourse of diversity management leads both organizations and individuals to treat linguistic and communicative inequality as a matter of individual responsibility.

\section{Challenges of Traditional Understandings of Intercultural Workplace}

\section{Communication}

Our contemporary understanding of the topic of intercultural workplace communication has evolved and transcended its original settings. Due to the increasing pluralization of the social landscape, communicating with persons of backgrounds different from one's own has become a staple working life experience for many. Issues of communicating interculturally at work are both globally relevant and locally contingent.

The scholarship into intercultural workplace communication employs a variety of methodologies to examine a range of workplace communication phenomena in both their task and relational dimensions. This complex topography tells us that issues of intercultural 
communication in the workplace are multifaceted. Gaining a profound understanding calls for attention to a range of communication phenomena and processes.

However, when we examine the three research perspectives jointly, we can see how the scholarship has produced incongruous insights into issues of intercultural communication as either a liability or as added value for individuals, teams, and organizations. What could be at play behind these conflicting findings? One could point to the predominant theoretical frameworks employed in the scholarship and to their underpinning notions of culture and intercultural communication.

The information and decision-making framework examines how differences associated with individuals' culturally shaped interpretations, knowledge, and skills hinder or enhance workplace performance. Cultural differences may affect processes such as achieving shared understanding, problem-solving, or innovation. The social identity and categorization framework considers national and ethnic memberships as potentially organizationally disruptive. They are obvious common denominators that may prompt people to form subgroups and develop biased views of other groups. The critical modern framework reveals the personal and organizational costs of systemic discrimination against cultural minority employees.

All the three frameworks presume the foundational role of nationality or ethnicity in shaping interaction. Moreover, they all see nation- and ethnicity-based cultural traits as stable, and as universally shared and experienced. This understanding can be traced to the mainstream theorizing in the field of intercultural communication exemplified by the work of Edward Hall and Geert Hofstede. Critics (e.g., Holliday, 2011; Piller, 2012) have termed this view essentialist. Essentialism sees culture as the essence of individuals that is fundamental to, and can explain, people's communication practices. 
Traditional scholarship operating on the essentialist notion of culture has certainly produced an important contribution by creating awareness of and documenting communicative relativity. These investigations have sensitized us against naively assuming that all people are alike and equally positioned. They have established that individuals in workplaces around the world may have different values, constraints, and expectations, which all feed into their everyday communication.

Meanwhile, critical scholars (e.g., Holliday, 2011; Mendoza et al., 2002) have argued that the traditional conceptualizations of nation, ethnicity, and language as coherent and territorially bound systems that determine communication do not do justice to the context-specific, dynamic, processual, and open-ended ways through which individuals construct their cultural belongings in today's world. As Hunsinger (2006) points out, individuals cannot be defined by some permanent national or ethnic communities-they dynamically construe their cultural identities through interactions with myriad different groups and ideas. Similarly, in their discussion of the predominant approaches in international management literature, Sackmann and Phillips (2004) have argued that the traditional view where national cultures are routinely assumed to be fundamental to interaction no longer corresponds with the work realities in the globalizing world. The intensification of global interconnectedness has given rise to forms of cultural identification and interaction that problematize the essentialist understanding of nation, ethnicity, and language even further (Rubdy \& Alsagoff, 2014).

Intercultural workplace communication research has increasingly recognized the limitations of the predominant theoretical frameworks. Alternative approaches have been used that acknowledge nation, ethnicity, and language as dynamic, processual, and situated constructs. 


\section{Emergent Trends and Future Research Directions}

In what follows, emergent trends in research are discussed and used to make suggestions that could inform future inquiries. These suggestions concern both issues under investigation, as well as theoretical and methodological assumptions.

\section{Beyond the Polarized Understanding of Cultural Difference}

The popular theoretical frameworks offer only two scenarios for cultural difference to manifest itself in communication as either a liability (a cause of misunderstandings, intergroup conflict, and discrimination) or an asset (triggering innovation and synergy). The preponderance of studies reviewed focus on the negative effects of cultural difference on the accomplishment of work and employee well-being. The positive effects of cultural diversity seem to have received more attention in practitioner-oriented literature (e.g., Adler \& Gundersen, 2008). This justifies a call for systematic critical empirical inquiry into issues such as cultural synergy or intercultural learning.

Beyond that, the mixed findings underscore the unworkability of approaching the theme of intercultural workplace communication in terms of either challenges or gains. In an ethnographic study of knowledge-sharing processes in a multinational corporation in Denmark, Lauring (2009) demonstrated how none of the popular theoretical frameworks applied in intercultural workplace communication research provided sufficient explanations of patterns of intercultural interaction at work. In order to develop our understanding of complex workplace communication processes, we need integrated, rich, and nuanced insights into the messy everyday lived workplace realities. In these realities, issues of intercultural communication constantly evolve, taking a range of different shapes that may sometimes have serious social, material, and political implications 
(e.g., Ladegaard, 2013; Lauring, 2011; Piller \& Lising, 2014), and sometimes take no shape at all (e.g., Ryoo, 2005; Schnurr \& Zayts, 2013).

Adherence to cultural difference may also mean that we miss out on the similarity among people. Here, we should give a serious consideration to the role that the workplace context plays. The workplace is not just a container for random interactions among random individuals. Instead, it offers a range of important resources for people (e.g., roles, tasks, objectives) that allow them to accomplish things together.

\section{Increased Focus on Actual Intercultural Interaction}

Scholars interested in intercultural communication at work have seldom focused on actual workplace interactions. The bulk of research claims about intercultural communication at work is derived from indirect self-report data: large-scale questionnaires and surveys, interviews, and focus groups. Such data may shed light onto people's perceptions and interpretations of their workplace interactions, undeniably an important aspect of communication. However, research participants' reports are often used uncritically by researchers to reconstruct or make predictions about actual workplace interactions. What people report in a research interview may not bear a stable relationship to what they do in their everyday lives (Silverman, 2006, p. 39).

The concern for examining what it is that people do in interaction ties in with a social constructionist orientation that questions the "naturalness" of culture and cultural identity as something people carry inside them and reveal in communication. For instance, Mendoza et al. (2002) have urged communication scholars to use alternative communication-based frameworks that would acknowledge the role of communication in constructing rather than expressing cultural identity. Working with observational and naturally-occurring data enables researchers to 
examine how people perform intercultural communication at work or, the exploration of "who makes culture relevant, to whom, how, in which context and for what purposes?" (Piller, 2011, p. 72).

Today's intercultural professional communication increasingly occurs in technologymediated ways (see Gibson et al., 2014). Since most technology-mediated interactions can be easily captured, researchers could gain access to records of actual communication and obtain direct insights into such organizing processes as cultural/team/organizational identification, leadership, task distribution, feedback, relational maintenance, knowledge sharing, decisionmaking, or learning. In a recent review of virtual team literature (Gilson, Maynard, Jones, Vartiainen, \& Hakonen, 2015), the authors conclude that working with records of actual team interactions has surprisingly remained a largely untapped opportunity among scholars.

\section{Towards Thick Descriptions of Small Cultures}

With the project of distilling and mapping nation-, ethnicity-, and language-based cultures receiving growing criticism, what is the future of cultural description? Holliday's (1999) concept of small culture, or a set of practices developed over time as a group of people engage in joint activities, could be useful for researchers interested in interactions in working life, for instance in the context of companies, groups, teams, or relationships. It enables a dynamic and situated study of group practices: how people negotiate shared norms and interpretations through their everyday collaboration. This shifts the focus away from cultural difference and onto what comes to be constructed as shared. Small culture is related to shared culture and interculture (Schnurr \& Zayts, 2013), third space (Bhabha, 1994), and shared communication competence. The application of these concepts is ideally supported by longitudinal qualitative research designs. In 
longitudinal research, organizations, work groups, or teams are followed through time to identify and explore their evolving processes, turning points or interpretive frameworks (e.g., Hermanowicz, 2016).

A number of novel studies do not explicitly employ the aforementioned concepts. However, they use a longitudinal ethnographic research design to construct rich and textured descriptions of what is going on when people who grew up in different places and speak different first languages interact at work and construct a pool of shared meanings and practices (e.g., Barinaga, 2007; Brannen \& Salk, 2000; Jansson, 2014; Murphy, 2013; Ogbonna \& Harris, 2006). These studies document how cultural difference is dynamically constructed in specific workplaces, with all the complexities, ambiguities, and nuances, and with sensitivity to issues of power and the larger context the workplace is embedded in.

Investigations that work with the concept of ethnicized community of practice (e.g., Marra \& Holmes, 2008) have also contributed to our understanding of how work groups may construct their shared ethnicity through everyday practices. However, it is important to see these discursive practices as locally emergent and contingent and not draw on the findings to make predictions about the whole ethnic group.

\section{Expanding the Treatment of Language}

While a lion's share of intercultural communication takes place in a language that is a second language to at least one of the parties involved, concerns related to people's competence in the language of the interaction have often been overlooked. Traditional scholarship has treated language as a neutral means for expressing national and ethnic cultures. While miscommunication is identified at the linguistic level, the phenomenon of miscommunication is 
explained at the deeper "cultural" level (Sarangi, 1994, p. 414) often identified as national speaking cultures or national communication styles.

We can develop new understandings with valuable implications for organizational practice through examining language as a social, rather than cultural, tool in working life. Language choice and linguistic competences can be a powerful resource for identification or social exclusion (Holmes \& Riddiford, 2010; Lauring, 2008), and they may exert a profound impact on patterns of interaction at work (Tange \& Lauring, 2009). Moreover, recent investigations employing records of authentic workplace interactions (e.g., Franziskus \& Gilles, 2012; Jansson, 2014; Lüdi, 2013) have documented how people creatively draw on their various linguistic resources to solve local problems and build shared understanding in ways that challenge the traditional concepts of language, linguistic competence, and bilingualism.

\section{Further Reading}

Barinaga, E. (2007). "Cultural diversity" at work: "National culture" as a discourse organizing an international project group. Human Relations, 60, 315-340.

Breidenbach, J., \& Nyíri, P. (2009). The age of "cultural competence.” Seeing culture everywhere: From genocide to consumer habits (pp. 262-318). Seattle: University of Washington Press.

Ely, R. J., \& Thomas, D. A. (2001). Cultural diversity at work: The effects of diversity perspectives on work group processes and outcomes. Administrative Science Quarterly, 46, $229-273$.

Gibson, C. B., Huang, L., Kirkman, B. L., \& Shapiro, D. L. (2014). Where global and virtual meet: The value of examining the intersection of these elements in twenty-first-century 
teams. Annual Review of Organizational Psychology and Organizational Behavior, 1, 217244.

Hofstede, G. (2001). Culture's consequences: Comparing values, behaviours, institutions and organisations across nations (2d ed.). Thousand Oaks, CA: SAGE.

Hua, Z. (2014). Piecing together the "workplace multilingualism" jigsaw puzzle. Multilingua, $33,233-242$.

Konrad, A. M. (2003). Defining the domain of workplace diversity scholarship. Group and Organization Management, 28(1), 4-17.

Lauring, J. (2009). Managing cultural diversity and the process of knowledge sharing: A case from Denmark. Scandinavian Journal of Management, 25, 385-394.

Piller, I. (2011). Intercultural communication at work. Intercultural communication: A critical introduction (pp. 76-95). Edinburgh: Edinburgh University Press.

Sackmann, S. A., \& Phillips, M. E. (2004). Contextual influences on culture research: Shifting assumptions for new workplace realities. International Journal of Cross Cultural Management, 4, 370-390.

Stahl, G. K., Maznevski, M. L. Voight, A., \& Jonsen, K. (2010). Unravelling the effects of cultural diversity in teams: A meta-analysis of research on multicultural work groups. Journal of International Business Studies, 41, 690-709.

Ting-Toomey, S., \& Oetzel, J. G. (2001). Managing intercultural conflict effectively. Thousand Oaks, CA: SAGE. 


\section{References}

Adler, N., \& Gundersen, A. (2008). International dimensions of organizational behavior (5th ed.). Mason, $\mathrm{OH}$ : Thomson Higher Education.

Al-Jenaibi, B. (2011). The scope and impact of workplace diversity in the United Arab Emirates: An initial study. Journal for Communication and Culture, 1, 49-81.

Angouri, J. (2013). The multilingual reality of the multinational workplace: Language policy and language use. Journal of Multilingual and Multicultural Development, 34, 564-581.

Angouri, J., \& Miglbauer, M. (2014). "And then we summarise in English for the others": The lived experience of the multilingual workplace. Multilingua, 33, 147-172.

Aries, N. R. (2004). Managing diversity: The differing perceptions of managers, line workers, and patients. Health Care Management Review, 29, 172-180.

Aritz, J., \& Walker, R. C. (2014). Leadership styles in multicultural groups: Americans and East Asians working together. International Journal of Business communication, 51, 72-92.

Ashkanasy, N., Härtel, C., \& Daus, C. (2002). Diversity and emotion: The new frontiers in organizational behaviour research. Journal of Management, 28, 307-338.

Au, Y., \& Marks, A. (2012). "Virtual teams are literally and metaphorically invisible": Forging identity in culturally diverse virtual teams. Employee Relations, 3, 271-287.

Ayoko, O. B., Härtel, C. E. J., \& Callan, V. J. (2002). Resolving the puzzle of productive and destructive conflict in culturally heterogeneous workgroups: A communication accommodation theory approach. The International Journal of Conflict Management, 13, $165-195$. 
Bacharach, S. B., Bamberger, P. A., \& Vashdi, D. (2005). Diversity and homophily at work: Supportive relations among white and African-American peers. Academy of Management Journal, 48, 619-644.

Barinaga, E. (2007). "Cultural diversity" at work: "National culture” as a discourse organizing an international project group. Human Relations, 60, 315-340.

Baxter, L. A., \& Asbury, B. (2015). Critical approaches to interpersonal communication. In D. O. Braithwaite \& P. Schrodt (Eds.), Engaging theories in interpersonal communication: Multiple perspectives (2d ed., pp. 189-201). Los Angeles: SAGE.

Bhabha, H. (1994). The location of culture. London: Routledge.

Bilbow, G. T. (2002). Commissive speech act use in intercultural business meetings. International Review of Applied Linguistics in Language Teaching, 40, 287-303.

Blyton, P., \& Jenkins, J. (2007). Knowledge work. Key concepts in work (pp. 116-120). Thousand, CA: SAGE.

Braithwaite, D. O., Schrodt, P., \& Carr, K. (2015). Introduction: Meta-theory and theory in interpersonal communication research. In D. O. Braithwaite \& P. Schrodt (Eds.), Engaging theories in interpersonal communication: Multiple perspectives ( $2 \mathrm{~d}$ ed., pp. 1-20). Los Angeles: SAGE.

Brannen, M. Y., \& Salk, J. E. (2000). Partnering across borders: Negotiating organizational culture in a German-Japanese joint venture. Human Relations, 53, 451-487.

Breidenbach, J., \& Nyíri, P. (2009). The age of "cultural competence.” Seeing culture everywhere: From genocide to consumer habits (pp. 262-318). Seattle: University of Washington Press. 
de Bres, J., Holmes, J., Marra, M., \& Vine, B. (2010). Kia ora matua: Humour and the Maori language in the workplace. Journal of Asian Pacific Communication, 20, 46-68.

Brief, A. P., Umphress, E. E., Dietz, J., Burrows, J. W., Butz, R. M., \& Scholten, L. (2005). Community matters: Realistic group conflict theory and the impact of diversity. Academy of Management Journal, 48, 830-844.

Busch, D. (2010). Shopping in hospitality: Situational constructions of customer-vendor relationships among shopping tourists at a bazaar on the German-Polish border. Language and Intercultural Communication, 10, 72-89.

Byrnes, F. (2008). Intercultural communication in a development project in Samoa. Journal of Applied Linguistics, 3, 91-101.

Camiah, N., \& Hollinshead, G. (2003). Assessing the potential for effective cross-cultural working between "new” Russian managers and Western expatriates. Journal of World Business, 38, 245-261.

Charles, M. (2007). Language matters in global communication. Article based on ORA lecture, October 2006. Journal of Business Communication, 44, 260-282.

Charles, M., \& Marschan-Piekkari, R. (2002). Language training for enhanced horizontal communication: A challenge for MNCs. Business Communication Quarterly, 65, 9-29.

Chevrier, S. (2003). Cross-cultural management in multinational project groups. Journal of World Business, 38, 141-149.

Collier, S. (2011). Negotiating business, negotiating self: Crossing cultural borders in bilingual entrepreneurial contexts. Journal of Language, Identity, and Education, 10, 1-21.

Connaughton, S. L., \& Shuffler, M. (2007). Multinational and multicultural distributed teams: A review and future agenda. Small Group Research, 38, 387-412. 
Cooke, D., Brown, T. P., \& Zhu, Y. (2007). Beyond language: Workplace communication and the L2 worker. Journal of Asian Pacific Communication, 17, 83-103.

Cramton, C. D. (2001). The mutual knowledge problem and its consequences for dispersed collaboration. Organization Science, 12, 346-371.

Cramton, C. D., \& Hinds, P. (2005). Subgroup dynamics in internationally distributed teams: Ethnocentrism or cross-national learning? Research in Organizational Behavior, 26, 231263.

Croucher, S. M., Parrott, K., Zeng, C., \& Gomez, O. (2014). A cross-cultural analysis of organizational dissent and workplace freedom in five European economies. Communication Studies, 65, 298-313.

Dameron, S., \& Joffre, O. (2007). The good and the bad: The impact of diversity management on co-operative relationships. International Journal of Human Resource Management, 18, 2037-2056.

Deitch, E. A., Barsky, A., Butz, R. M., Chan, S., Brief, A. P., \& Bradley, J. C. (2003). Subtle yet significant: The existence and impact of everyday racial discrimination in the workplace. Human Relations, 56, 1299-1324.

Dekker, D., Rutte, C., \& Van den Berg, P. (2008). Cultural differences in the perception of critical interaction behaviors in global virtual teams. International Journal of Intercultural Relations, 32, 441-452.

Dickson, D., Hargie, O., \& Wilson, N. (2008). Communication, relationships, and religious difference in the Northern Ireland workplace: A study of private and public sector organizations. Journal of Applied Communication Research, 36, 128-160. 
Distefano, J. J., \& Maznevski, M. L. (2000). Creating value with diverse teams in global management. Organizational Dynamics, 29, 45-63.

Earley, P. C., \& Mosakowski, E. (2000). Creating hybrid team cultures: An empirical test of transnational team functioning. Academy of Management Journal, 43, 26-49.

Ely, R. J., \& Thomas, D. A. (2001). Cultural diversity at work: The effects of diversity perspectives on work group processes and outcomes. Administrative Science Quarterly, 46, $229-273$.

Fearfull, A., \& Kamenou, N. (2006). How do you account for it? A critical exploration of career opportunities for and experiences of ethnic minority women. Critical Perspectives on Accounting, 17, 883-901.

Ferguson, M., \& Porter, S. C. (2013). An examination of categorization processes in organizations: The root of intergroup bias and a route to prejudice reduction. In Q. Roberson (Ed.), The Oxford handbook of diversity and work (pp. 98-114). Oxford: Oxford University Press.

Franziskus, A., \& Gilles, P. (2012). “Et le prais direct etikett?” Non-overlapping repertoires in workplace communication in Luxembourg. Sociolinguistica, 26, 58-71.

García, M. C. M., \& Cañado, M. L. P. (2011). Multicultural teamwork as a source of experiential learning and intercultural development. Journal of English Studies, 9, 145-163.

Gavioli, L., \& Baraldi, C. (2011). Interpreter-mediated interaction in healthcare and legal settings: Talk organization, context and the achievement of intercultural communication. Interpreting, 13, 205-233. 
Gibbs, J., Nekrassova, D., Grushina, S., \& Wahab, S. (2008). Reconceptualizing virtual teaming from a constitutive perspective: Review, redirection, and research agenda. Communication Yearbook, 32, 187-229.

Gibson, C. B., \& Gibbs, J. L. (2006). Unpacking the concept of virtuality: The effects of geographic dispersion, electronic dependence, dynamic structure, and national diversity on team innovation. Administrative Science Quarterly, 51, 451-495.

Gibson, C. B., \& Grubb, A. R. (2005). Turning the tide in multinational teams. In D. L. Shapiro, M. A. Von Glinow, \& J. L. C. Cheng (Eds.), Managing multinational teams: Global perspectives (pp. 69-95). Advances in International Management, 18. Emerald Business, Management and Economics eBook Series Collection Emerald Group Publishing Limited.

Gibson, C. B., Huang, L., Kirkman, B. L., \& Shapiro, D. L. (2014). Where global and virtual meet: The value of examining the intersection of these elements in twenty-first-century teams. Annual Review of Organizational Psychology and Organizational Behavior, 1, 217244.

Gilson, L., Maynard, M. T., Jones, N., Vartiainen, M., \& Hakonen, M. (2015). Virtual teams research: 10 years, 10 themes, and 10 opportunities. Journal of Management, 41(5), 13131337.

Hall, E. (1989). Beyond culture. New York: Bantam Doubleday Dell.

Hall, E. (1990). The silent language. New York: Bantam Doubleday Dell

Henderson, J. K. (2005). Language diversity in international management teams. International Studies of Management \& Organization, 35, 66-82. 
Hermanowicz, J. C. (2016). Longitudinal qualitative research. In M. J. Shanahan, J. T.

Mortimer, \& M. K. Johnson (Eds.), Handbook of the life course (pp. 491-513). Springer International Publishing.

Hinds, P., \& Mortensen, M. (2005). Understanding conflict in geographically distributed teams: The moderating effects of shared identity, shared context, and spontaneous communication. Organization Science, 16, 290-307.

Hite, L. M., \& McDonald, K. S. (2006). Diversity training pitfalls and possibilities: An exploration of small and mid-size US organizations. Human Resource Development International, 9, 365-377.

Hofstede, G. (1980). Culture's consequences: International differences in work-related values. Beverly Hills, CA: SAGE.

Hofstede, G. (1991). Cultures and organizations: Software of the mind. London: McGraw-Hill.

Hofstede, G. (2001). Culture's consequences: Comparing values, behaviors, institutions and organisations across nations ( $2 \mathrm{~d}$ ed.). Thousand Oaks, CA: SAGE.

Hofstede, G. (2011). Dimensionalizing cultures: The Hofstede model in context. Online Readings in Psychology and Culture, 2(1). International Association for Cross-Cultural Psyhology.

Hofstede, G., Hofstede, G. J., \& Minkov, M. (2010). Cultures and organizations: Software of the mind ( $3 \mathrm{~d}$ ed.). New York: McGraw-Hill.

Holliday, A. (1999). Small cultures. Applied Linguistics, 20, 237-264.

Holliday, A. (2011). Key discussions. Intercultural communication and ideology (pp. 1-17). Thousand Oaks, CA: SAGE. 
Holmes, J., Marra, M., \& Schnurr, S. (2008). Impoliteness and ethnicity: Maori and Pakeha discourse in New Zealand workplaces. Journal of Politeness Research, 4, 193-219.

Holmes, J., \& Riddiford, N. (2010). Professional and personal identity at work: Achieving a synthesis through intercultural workplace talk. Journal of Intercultural Communication, 22.

Holmes, J., Vine, B., \& Marra, M. (2009). Maori men at work: Leadership, discourse, and ethnic identity. Intercultural Pragmatics, 6, 345-366.

Holvino, E., \& Kamp, A. (2009). Diversity management: Are we moving in the right direction? Reflections from both sides of the North Atlantic. Scandinavian Journal of Management, 25, $395-403$.

Hua, Z. (2014). Piecing together the "workplace multilingualism” jigsaw puzzle. Multilingua, $33,233-242$.

Hunsinger, R. P. (2006). Culture and cultural identity in intercultural technical communication. Technical Communication Quarterly, 15, 31-48.

Irizarry, C., \& Gallant, L. (2006). Managing diversity: Interpretation and enactment in a health care setting. Qualitative Research Reports in Communication, 7, 43-50.

Jansson, G. (2014). Bridging language barriers in multilingual care encounters. Multilingua, 33, $201-232$.

Kamenou, N., \& Fearfull, A. (2006). Ethnic minority women: A lost voice in HRM. Human Resource Management Journal, 16, 154-172.

Kamp, A., \& Hagedorn-Rasmussen, P. (2004). Diversity management in a Danish context: Towards a multicultural or segregated working life. Economic \& Industrial Democracy, 25, 525-554. 
Kingsley, L. (2013). Language choice in multilingual encounters in transnational workplaces. Journal of Multilingual and Multicultural Development, 34, 533-548.

Klarsfeld, A. (2009). The diffusion of diversity management: The case of France. Scandinavian Journal of Management, 25, 363-373.

Klitmøller, A., \& Lauring, J. (2013). When global virtual teams share knowledge: Media richness, cultural difference and language commonality. Journal of World Business, 48, 398406.

Ladegaard, H. (2013). Beyond the reach of ethics and equity? Depersonalisation and dehumanisation in foreign domestic helper narratives. Language and Intercultural Communication, 13, 44-59.

Lahti, M. (2013). Cultural identity in everyday interactions at work: Highly-skilled female Russian professionals in Finland. Nordic Journal of Working Life Studies, 3, 21-43.

Lahti, M. (2015a). Communicating interculturality in the workplace (Doctoral dissertation). Jyväskylä Studies in Humanities, 262. University of Jyväskylä, Jyväskylä, Finland. Retrieved from https://jyx.jyu.fi/dspace/handle/123456789/47257.

Lahti, M. (2015b). Sharing cultural knowledge at work: A study of chat interactions of an internationally dispersed team. Language and Intercultural Communication, 15, 513-532.

Lauring, J. (2008). Rethinking social identity theory in international encounters: Language use as a negotiated object for identity making. International Journal of Cross Cultural Management, 8, 343-361.

Lauring, J. (2009). Managing cultural diversity and the process of knowledge sharing: A case from Denmark. Scandinavian Journal of Management, 25, 385-394. 
Lauring, J. (2011). Intercultural organizational communication: The social organizing of interaction in international encounters. Journal of Business Communication, 48, 231-255.

Leeds-Hurwitz, W. (1990). Notes in the history of intercultural communication: The Foreign Service Institute and the mandate for intercultural training. Quarterly Journal of Speech, 76, 262-281.

Litvin, D. (2006). Diversity: Making space for a better case. In A. M. Konrad, P. Prasad \& J. K. Pringle (Eds.), Handbook of workplace diversity (pp. 75-94). Thousand Oaks, CA: SAGE.

Lockwood, J. (2015). Virtual team management: What is causing communication breakdown? Language and Intercultural Communication, 15, 125-140.

Lønsmann, D. (2014). Linguistic diversity in the international workplace: Language ideologies and processes of exclusion. Multilingua, 33(1-2), 89-116.

Loosemore, M., \& Lee, P. (2002). Communication problems with ethnic minorities in the construction industry. International Journal of Project Management, 20, 517-524.

Lorbiecki, A., \& Jack, G. (2000). Critical turns in the evolution of diversity management. British Journal of Management, 11, S17-S31.

Louhiala-Salminen, L., Charles, M., \& Kankaanranta, A. (2005). English as a lingua franca in Nordic corporate mergers: Two case companies. English for Specific Purposes, 24, 401-421. Lüdi, G. (2013). Receptive multilingualism as a strategy for sharing mutual linguistic resources in the workplace in a Swiss context. International Journal of Multilingualism, 10, 140-158.

Luijters, K., van der Zee, K. I., \& Otten, S. (2008). Cultural diversity in organizations: Enhancing identification by valuing differences. International Journal of Intercultural Relations, 32, 154-163. 
Mahili, I. (2014). "It's pretty simple and in Greek . . .": Global and local languages in the Greek corporate setting. Multilingua, 33, 117-146.

Mak, B. C. N., \& Chui, H. L. (2013). A cultural approach to small talk: A double-edged sword of sociocultural reality during socialization into the workplace. Journal of Multicultural Discourses, 8(2), 118-133.

Mannix, E., \& Neale, M. (2005). What differences make a difference? The promise and reality of diverse teams in organizations. Psychological Science in the Public Interest, 6, 31-55.

Marra, M., \& Holmes, J. (2008). Constructing ethnicity in New Zealand workplace stories. Text and Talk, 28, 397-419.

Matveev, A.V. (2004). Describing intercultural communication competence: In-depth interviews with American and Russian managers. Qualitative Research Reports in Communication, V, 55-62.

Matveev, A. V., \& Nelson, P. E. (2004). Cross cultural communication competence and multicultural team performance. International Journal of Cross Cultural Management, 4(2), $253-270$.

Mayer, C.-H., \& Louw, L. (2012). Managerial values in transcultural conflicts in South Africa. Journal of Intercultural Communication, 30, XX-XX.

McCann, R. M., \& Giles, H. (2006). Communication with people of different ages in the workplace: Thai and American data. Human Communication Research, 32, 74-108.

Meares, M., Oetzel, J., Torres, A., Derkacs, D., \& Ginossar, T. (2004). Employee mistreatment and muted voices in the culturally diverse workplace. Journal of Applied Communication Research, 32, 4-27. 
Mendoza, S. L., Halualani, R. T., \& Drzewiecka, J. A. (2002). Moving the discourse on identities in intercultural communication: Structure, culture, and resignifications. Communication Quarterly, 50, 312-327.

Moon, D. (1996). Concepts of "culture": Implications for intercultural communication research. Communication Quarterly, 44, 70-84.

Murphy, A. G. (2013). Discursive frictions: Power, identity, and culture in an international working partnership. Journal of International and Intercultural Communication, 6, 1-20.

Nazione, S., \& Silk, K. (2011). Employees' views of discrimination in a community health department. The Howard Journal of Communications, 22, 200-221.

Nelson, M. (2014). "You need help as usual, do you?”: Joking and swearing for collegiality in a Swedish workplace. Multilingua, 33, 173-200.

Ngai, P. B.-Y. (2000). Nonverbal communicative behavior in intercultural negotiations: Insights and applications based on findings from Ethiopia, Tanzania, Hong Kong, and the China mainland, World Communication, 29, 5-35.

Oetzel, J., McDermott, V. M., Torres, A., \& Sanchez, C. (2012). The impact of individual differences and group diversity on group interaction climate and satisfaction: A test of the effective intercultural workgroup communication theory. Journal of International and Intercultural Communication, 5, 144-167.

Ogbonna, E., \& Harris, L. (2006). The dynamics of employee relationships in an ethnically diverse workforce. Human Relations, 59, 379-407.

Okamura, A. (2009). Do English speakers address their Japanese colleagues by their first name, while talking in English in Japan? Multilingua, 28, 355-377. 
Omanovic, V. (2009). Diversity and its management as a dialectical process: Encountering Sweden and the US. Scandinavian Journal of Management, 25, 352-362.

Ostendorp, A., \& Steyaert, C. (2009). How different can differences be(come)? Interpretive repertoires of diversity concepts in Swiss-based organizations. Scandinavian Journal of Management, 25, 374-384.

Otsuji, E., \& Pennycook, A. (2010). Metrolingualism: Fixity, fluidity and language in flux. International Journal of Multilingualism, 7(3), 240-254.

Pal, M., \& Buzzanell, P. (2008). The Indian call center experience: A case study in changing discourses of identity, identification, and career in a global context. Journal of Business Communication, 45(1), 31-60.

Park, J., S.-Y. (2013). Metadiscursive regimes of diversity in a multinational corporation. Language in Society, 42, 557-577.

Parker, P. (2001). African American women executives' leadership communication within dominant-culture organizations: (Re)conceptualizing notions of collaboration and instrumentality. Management Communication Quarterly, 15(1), 42-82.

Parker, P. (2002). Negotiating identity in raced and gendered workplace interactions: The use of strategic communication by African American women senior executives within dominant culture organizations. Communication Quarterly, 50(3), 251-268.

Peltokorpi, V. (2007). Intercultural communication patterns and tactics: Nordic expatriates in Japan. International Business Review, 16, 68-82.

Piller, I. (2011). Intercultural communication: A critical introduction. Edinburgh: Edinburgh University Press. 
Piller, I. (2012). Intercultural communication: An overview. In C. Paulston, S. Kiesling, \& E. Rangel (Eds.), The handbook of intercultural discourse and communication (pp. 3-18). Wiley-Blackwell.

Piller, I., \& Lising, L. (2014). Language, employment, and settlement: Temporary meat workers in Australia. Multilingua, 33(1-2), 35-59.

Pompper, D. (2007). The gender-ethnicity construct in public relations organizations: Using feminist standpoint theory to discover Latinas' realities. The Howard Journal of Communications, 18, 291-311.

Prasad, A. (2001). Understanding workplace empowerment as inclusion: A historical investigation of the discourse of difference in the US. The Journal of Applied Behavioural Science, 37(1), 51-69.

Pullin, P. (2010). Small talk, rapport, and international communicative competence: Lessons to learn from BELF. Journal of Business Communication, 47(4), 455-476.

Richardson, B. K., \& Taylor, J. (2009). Sexual harassment at the intersection of race and gender: A theoretical model of the sexual harassment experiences of women of colour. Western Journal of Communication, 73(3), 248-272.

Rubdy, R., \& Alsagoff, L. (2014). The cultural dynamics of globalisation: Problematising hybridity. In R. Rubdy \& L. Alsagoff (Eds.), The global-local interface and hybridity: Exploring language and identity (pp. 1-14). Bristol, U.K.: Multilingual Matters.

Ryoo, H.-K. (2005). Achieving friendly interactions: A study of service encounters between Korean shopkeepers and African-American customers. Discourse \& Society, 16(1), 79-105. 
Sackmann, S. A., \& Phillips, M. E. (2004). Contextual influences on culture research: Shifting assumptions for new workplace realities. International Journal of Cross Cultural Management, 4(3), 370-390.

Salk, J. E., \& Brannen, M. Y. (2000). National culture, networks, and individual influence in a multinational management team. Academy of Management Journal, 43(2), 191-202.

Sarangi, S. (1994). Intercultural or not? Beyond celebration of cultural differences in miscommunication analysis. Pragmatics, 4(3), 409-427.

Schnurr, S., \& Zayts, O. (2013). "I can’t remember them ever not doing what I tell them!": Negotiating face and power relations in "upward" refusals in multicultural workplaces in Hong Kong. Intercultural Pragmatics, 10(4), 593-616.

Scott, M. (2013). “Communicate through the roof': A case study analysis of the communicative rules and resources of an effective global virtual team. Communication Quarterly, 61(3), 301-318.

Shi, Y. (2008). Chinese immigrant women workers: Everyday forms of resistance and “coagulate politics.” Communication and Critical/Cultural Studies, 5(4), 363-382.

Shin, J.-H., Heath, R. L., \& Lee, J. (2011). A contingency explanation of public relations practitioner leadership styles: Situation and culture. Journal of Public Relations Research, 23(2), 167-190.

Sias, P. M. (2009). Organizing workplace relationships. Organizing relationships: Traditional and emerging perspectives on workplace relationships (pp. 1-18). Los Angeles: SAGE.

Sias, P. M., \& Cahill, D. J. (1998). From coworkers to friends: The development of peer friendships in the workplace. Western Journal of Communication, 62(3), 273-299. 
Silverman, D. (2006). Interpreting qualitative data: Methods for analysing talk, text and interaction (3d ed.). Los Angeles: SAGE.

Soni, V. (2000). A twenty-first-century reception for diversity in the public sector: A case study. Public Administration Review, 60(5), 395-408.

Stahl, G. K., Maznevski, M. L., Voigt, A., \& Jonsen K. (2010). Unravelling the effects of cultural diversity in teams: A meta-analysis of research on multicultural work groups. Journal of International Business Studies, 41, 690-709.

Sun, J. (2013). Training the trainers: What do professional communicators need to be aware of in intercultural communication? China Media Research, 9(3), 74-83.

Sunaoshi, Y. (2005). Historical context and intercultural communication: Interactions between Japanese and American factory workers in the American south. Language in Society, 34, $185-217$.

Tajfel, H., \& Turner, J. C. (1979). An integrative theory of inter-group conflict. In W. B. Austin \& S. Worchel (Eds.), Psychology of intergroup relations (pp. 33-47). Chicago: Nelson-Hall.

Tanaka, H. (2006). Emerging English-speaking business discourses in Japan. Journal of Asian Pacific Communication, 16(1), 25-50.

Tange, H., \& Lauring, J. (2009). Language management and social interaction within the multilingual workplace. Journal of Communication Management, 13(3), 218-232.

Trompenaars, F., \& Hampden-Turner, C. (1997). Riding the waves of culture: Understanding cultural diversity in business. London: Nicholas Brealey.

Turner, J.C. (1987). A self-categorization theory. In J. C. Turner, M. A. Hogg, P. J. Oakes, S. D. Reicher, \& M. S. Wetherell (Eds.), Rediscovering the social group: A selfcategorization theory (pp. 42-67). Oxford: Blackwell. 
Turner, L. H., \& Shuter, R. (2004). African American and European American women's visions of workplace conflict: A metaphorical analysis. The Howard Journal of Communications, 15, 169-183.

Ulrey, K. L., \& Amason, P. (2001). Intercultural communication between patients and health care providers: An exploration of intercultural communication effectiveness, cultural sensitivity, stress, and anxiety. Health Communication, 13(4), 449-463.

Vallaster, C. (2005). Cultural diversity and its impact on social interactive processes: Implications from an empirical study. International Journal of Cross Cultural Management, 5(2), 139-163.

Wang, J., \& Murphy, P. (2010). In the office vs. outside the office: Supervisor-subordinate guanxi maintenance among Chinese and Western managers in China. Chinese Journal of Communication, 3(2), 147-166.

Welch, D., Welch, L., \& Marschan-Piekkari, R. (2001). The persistent impact of language on global operations. Prometheus, 19(3), 193-209.

Westerman, C. Y. K., Park, H. S., \& Lee, H.-E. (2007). Cultural differences in the effects of inequity on coworker friendships. Human Communication, 10(2), 82-102.

Wrench, J. (2005). Diversity management can be bad for you. Race \& Class, 46(3), 73-84.

Wu, M., \& Buzzanell, P. (2013). Liminalities at work: Chinese professionals’ immigrant identity negotiations. China Media Research, 9(4), 15-26.

Wu, M.-Y. (2008). Comparing expected leadership styles in Taiwan and the United States: A study of university employees. China Media Research, 4(1), 36-46.

Zaidman, N., \& Drory, A. (2001). Upward impression management in the workplace crosscultural analysis. International Journal of Intercultural Relations, 25, 671-690. 
Zakaria, N., Amelinckx, A., \& Wilemon, D. (2004). Working together apart? Building a knowledge sharing culture for global virtual teams. Creativity and Innovation Management, $13,15-29$.

Zanoni, P., \& Janssens, M. (2007). Minority employees engaging with (diversity) management: An analysis of control, agency, and micro-emancipation. Journal of Management Studies, 46(8), 1371-1397. 